\begin{tabular}{c|c|c}
\hline \hline Vol. 251: 299-310, 2003 & MARINE ECOLOGY PROGRESS SERIES \\
Mar Ecol Prog Ser & Published April 11 \\
\hline \hline
\end{tabular}

\title{
Decadal-scale seabird assemblages in Prydz Bay, East Antarctica
}

\author{
Eric J. Woehler*, Ben Raymond, David J. Watts \\ Australian Antarctic Division, Channel Highway, Kingston, Tasmania 7050, Australia
}

\begin{abstract}
A total of 26 species/taxa make up the seabird community of Prydz Bay, East Antarctica, of which 9 are resident breeding species. Analyses of almost 32000 at-sea observations over $20 \mathrm{yr}$ (1980/81 to 2001/02) identified 3 assemblages. Observations of Assemblage 1, which included the 9 resident species, were consistent with the influx, presence and departure of breeding birds to their colonies around Prydz Bay. Assemblage 2 was comprised of all seabird species/taxa reported from Prydz Bay and represented an overlap (in time and space) assemblage, being observed in late summer in central Prydz Bay. Assemblage 3 consisted principally of the non-resident species/taxa that visit Prydz Bay every summer from sub-Antarctic and temperate breeding localities. This assemblage was observed most frequently in mid to late summer and well offshore. Two species were found to be indicator species of all 3 assemblages; this is proposed to be a result of their Antarctic and subAntarctic breeding distributions that in turn produce broad ranges in their at-sea distributions in the Southern Ocean. Assemblage 1 is similar to the pack-ice associated seabird assemblage identified elsewhere around the Antarctic, differing only in species composition due to species' breeding distributions at regional scales. Analyses at finer temporal scales (decadal and semi-decadal) identified the same assemblages, indicating the stability of seabird assemblages over the 1980/81 to 2001/02 period within Prydz Bay.
\end{abstract}

KEY WORDS: Seabirds at sea $\cdot$ Community dynamics $\cdot$ Seabird assemblages $\cdot$ Penguins $\cdot$ Petrels $\cdot$ Albatrosses · Antarctica $\cdot$ Southern Ocean

\section{INTRODUCTION}

Seabird at-sea assemblages in the Southern Ocean have been examined in the Ross Sea (Ainley et al. 1984) and in the South Atlantic (Ainley et al. 1986, 1992, 1993). Two distinct assemblages have been recognised, one constrained to the Antarctic pack-ice, and the other to open water (Fraser \& Ainley 1986, Ainley et al. 1992, 1993). The relative contributions of biotic and abiotic components of the environment in determining these assemblages around the Southern Ocean is still unknown (Ainley et al. 1993); nor is it known whether these components attract or restrict the assemblages to specific habitats. While components of the physical environment have been suggested as determinants (e.g. wind regime: Griffiths 1983, pack-ice cover: Ainley et al. 1994, ice-edge:
Fraser \& Ainley 1986, surface water characteristics: Abrams 1985, Eakin et al. 1986, Hunt et al. 1990, bathymetry: Ainley \& Jacobs 1981 and circulation: Nicol et al. 2000), so too have biological characteristics such as productivity and prey distributions (Griffiths et al. 1982, Hunt et al. 1990, Ainley et al. 1992, Nicol et al. 2000) and competition (Ainley et al. 1994). At-sea studies of Antarctic seabird communities permit an understanding of the role of the physical and biological environments on temporal and spatial patterns in seabird distribution, influences on trophic interactions, and provide data on the potential use of seabirds as indicators of signals from their environment. As seabirds can spend in excess of $65 \%$ of their lives at sea removed from colony-based studies (Fraser \& Ainley 1986), at-sea studies not only complement colony-based studies but provide insight into the inter- 
action between seabirds and their environment that can not be readily elucidated from colony studies.

In the Antarctic, major breeding seabird populations are present along the Ross Sea coast, on the Antarctic Peninsula and around Prydz Bay. These 3 foci comprise the majority of seabird populations and biomass within the Antarctic (Watson 1975). Prydz Bay, on the coast of East Antarctica in the southwest Indian Ocean, has been the focus of long-term seabird studies since the international Biological Investigations of Marine Antarctic Systems and Stocks (BIOMASS) programme that commenced in the early 1980s (Cooper \& Woehler 1994, Woehler 1997). Prydz Bay is the primary seabird breeding locality in East Antarctica, with breeding populations of 9 species (Woehler \& Johnstone 1991), comprising approximately $30 \%$ of that East Antarctic seabird biomass (Woehler 1990). Seabird at-sea studies within Prydz Bay have estimated prey consumption by the seabird community (Cooper \& Woehler 1994, Woehler 1997), the energy flux to the seabird community (Woehler 1997) and reported on long-term decreases in at-sea abundances of species, individuals of which are known to be taken in long-line fisheries elsewhere in the Southern Ocean (Woehler 1996, Woehler \& Watts 2000). Long-term (decadal-scale) trends in breeding populations in the area have also been quantified (Woehler et al. 2001).

The present study examines the decadal-scale (20 yr) seabird at-sea assemblages observed in Prydz Bay, the relationship between these assemblages and aspects of the physical environment, and quantifies the fidelity and constancy of the species compositions of the assemblages identified.

\section{MATERIALS AND METHODS}

Seabird and environmental observations. Details of the observation methodology have been described previously (Woehler 1995, 1997). As with these previous studies, Prydz Bay has been defined as being between 60 and $90^{\circ} \mathrm{E}$, and south of $60^{\circ} \mathrm{S}$ to the Antarctic continent. Seabird observations from 1982/83 were excluded from analyses as a different methodology was used for those data. No seabird data were collected within Prydz Bay during 1994/95. Data for taxa that are difficult to identify specifically at sea (e.g. prions Pachyptila spp. and dark shearwaters Puffinus spp.) have been pooled for analyses (Woehler 1997). A total of 14 species/taxa with fewer than 10 observations in the 20 yr were excluded from analyses (Appendix 1).

Physical environmental data collected contemporaneously with seabird observations comprised sea surface temperature $\left({ }^{\circ} \mathrm{C}\right)$, sea state (Beaufort), cloud cover (oktas), precipitation (precipitation types), wind force
(Beaufort) and air pressure (hPa). Sea-ice cover (tenths) was also estimated by observers during seabird observations. However, for the analyses presented here, we used an estimate of sea-ice cover from passive microwave satellite sensing (Comiso 1999, 2002; http://nsidc.org/data/sea_ice.html) to overcome the potential fine-scale biases of ship tracks being chosen through areas of open water (i.e. less sea-ice) and leads. The pixel size for satellite-sourced ice cover data was $25 \times 25 \mathrm{~km}$, approximately twice the distance to the horizon for the ship-based observers ( 12 km horizon from the on-board observation point).

Statistical analyses. Seabird observation records were collected during $10 \mathrm{~min}$ periods. In order to reduce the computational demands of the analyses, consecutive observation records from a single voyage were pooled to form composite records. The pooling was undertaken such that observations within a composite record spanned no more than $12 \mathrm{~h}$ and a $50 \mathrm{~km}$ change in ship position. Environmental variable values within a composite record were combined using a median (for continuous variables), or mode (for nominal or ordinal variables). The species composition of each composite record was compiled in presence/ absence format, with presence determined by the presence of a species/taxon within any of the original records. Here, we refer to composite records as sites, since each composite record corresponds to a unique space-time location.

Seabird groupings were explored by 2 types of cluster analysis. The first was a clustering of sites based on the species composition. Dissimilarities between sites were calculated using Bray-Curtis distances and the extended-dissimilarity technique of De'ath (1999). Extended dissimilarities offer robust estimation of ecological distance across long ecological gradients, where there are sites with disjoint species compositions. The dissimilarity between a pair of sites with no species in common is estimated by the sum of dissimilarities with an intermediate site, which has species in common with both members of the pair.

Seabird groupings were derived from these dissimilarities using a hierarchical, complete-linkage clustering. Cluster analysis attempts to recover the natural groupings within the data. However, species community data rarely form distinct clusters; rather, smooth transitions between communities along ecological gradients are more likely. In this situation, the subdivision of the data into communities is in some sense arbitrary, since the cluster boundaries will depend to some extent on the numerical properties of the clustering algorithm. This is particularly true if (as in this case) the data are sparse, since cluster boundaries will tend to form at discontinuities in the data. The resulting groupings may be numerically, but not ecologically, 
significant. Here, we chose to extract a large number of clusters from the dendrogram (up to 10 groups) and then selectively re-merge small groups with little apparent ecological significance into their parent clusters during a manual post-processing of the dendrogram. Complete-linkage clustering was used because it tends to create compact groups of approximately equal size, thereby avoiding 'chaining' along the species composition gradient.

The groupings identified using this approach are referred to here as assemblages. Two indices were calculated to assist in characterising these assemblages. The first, assemblage fidelity, is a measure of the specificity of a particular species/taxon to a given assemblage, and is unity if observations of that species/taxon are only made within that assemblage. The second index, assemblage constancy, is a measure of the relative frequency of species/taxa within the assemblage, and will be unity if every site within the assemblage includes the species/taxon. The assemblage constancy may be thought of as the average species composition of sites within a cluster. Species/taxa with a high fidelity-constancy product can be used to characterise an assemblage (Dufrêne \& Legendre 1997), and those species with a fidelity-constancy product of 0.05 or greater were identified as indicator species/taxa for assemblages in this study. The value of 0.05 was used on the basis that the histograms of fidelity-constancy product values showed a discontinuity at this value for all assemblages, indicating a dichotomy between indicator and non-indicator species/taxa.

The temporal stability of the assemblages was assessed by repeating the assemblage analyses outlined above using subsets of the data. The available data were divided into 2 groups (1980/81-1990/91 and 1991/92-2001/02) and 4 periods (1980/81-1985/86, $1986 / 87-1990 / 91$, 1991/92-1996/97 and 1997/982001/02). The results obtained in these analyses were then compared between and among the periods and to the findings from all years combined.

The second approach used to explore the seabird communities was a hierarchical, complete-linkage clustering of the site ranges of the species/taxa. Dissimilarities between the site ranges of species/taxa were calculated using the 2-step algorithm (Austin \& Belbin 1982). This approach is complementary to the first, and identifies groups of bird species/taxa according to similarities in their distributions in space and time. Groupings of seabirds identified using this approach are referred to here as associations, in order to distinguish between the 2 approaches.

The relationship between species assemblage and physical environment were explored heuristically using a predictive approach utilising classification trees (Brieman et al. 1984). The species group (assem- blage number) for each site was used as the response variable, and various combinations of environmental, spatial, and temporal variables were used as explanatory variables. Each tree was grown to an over-large size, and pruned by cross-validation to find the tree with the highest predictive accuracy. Cross-validation was performed by voyage; i.e. classification trees were built using data from a subset of the available voyages, and data from the remaining voyages were used to test the predictive accuracy of the tree. Since the environmental variables and the observed species both change slowly with respect to the ship speed, successive observations on a single voyage are likely to be very similar (i.e. autocorrelated). Failing to crossvalidate by voyage was found to lead to over-optimistic estimates of predictive accuracy, since a datum in the validation set could potentially be only incrementally different from the data subset used to build the tree.

\section{RESULTS}

Observations were made in Prydz Bay in 20 of the 22 yr between 1980/81 and 2001/02. No at-sea observations were made within Prydz Bay between late May and early September inclusive over the $22 \mathrm{yr}$. A total of 31847 at-sea observations of 26 species/taxa were analysed here (Table 1, Fig. 1). The 9 resident species (see Table 1) accounted for $72.3 \%$ of all observations. A mean of $19.3 \pm 2.6$ species/taxa was observed within Prydz Bay each year. All scientific names are given in Table 1 and Appendix 1. The Spearman correlations among environmental variables are presented in Table 2.

\section{Seabird assemblages}

Three seabird assemblages were identified within Prydz Bay for the period 1980/81 to 2001/02 (Figs. 2-4). The species composition, temporal and spatial characteristics for the 3 assemblages are detailed below, and their spatiotemporal distributions within Prydz Bay are shown in Fig. 4. Each panel in this figure extends from the middle of one month to the middle of the following month (e.g. 15 October to 14 November). This timing was selected to synchronise with the breeding phenologies of the 9 resident species, as previously applied (Woehler 1997). These 3 assemblages were obtained by truncating the dendrogram at the 5-group level. These 5 groups included 2 small groups (of sizes 18 and 1 sites) with little apparent ecological significance. Each of the sites within these 2 groups was merged into the closest of the 3 larger groups. The final group sizes were 766, 562 and 519 sites. 
Table 1. Species/taxa observed within Prydz Bay, 1980/81 to 2001/02

\begin{tabular}{|c|c|c|c|}
\hline Code & Common name & Scientific name & $\begin{array}{l}\text { mber of } \\
\text { ervations }\end{array}$ \\
\hline \multicolumn{4}{|c|}{ Species that breed around Prydz Bay: } \\
\hline EMPE & Emperor penguin & Aptenodytes forsteri & 714 \\
\hline ADPE & Adélie penguin & Pygoscelis adeliae & 3398 \\
\hline SGPE & Southern giant petrel & Macronectes giganteus & 587 \\
\hline SOFU & Southern fulmar & Fulmarus glacialoides & 2977 \\
\hline CAPE & Cape petrel & Daption capense & 2312 \\
\hline ANPE & Antarctic petrel & Thalassoica antarctica & 4703 \\
\hline SNPE & Snow petrel & Pagodroma nivea & 5202 \\
\hline WISP & Wilson's storm petrel & Oceanites oceanicus & 2677 \\
\hline SPSK & South polar skua & Catharacta maccormicki & 459 \\
\hline \multicolumn{4}{|c|}{ Species/taxa that breed elsewhere: } \\
\hline SUSK & Subantarctic skua & Catharacta lonnbergi & 35 \\
\hline ANTE & Antarctic tern & Sterna vittata & 31 \\
\hline ARTE & Arctic tern & Sterna paradisaea & 280 \\
\hline AATE & Arctic/Antarctic tern & Sterna paradisaea \& S. vittata & 142 \\
\hline WAAL & Wandering albatross & Diomedea exulans & 102 \\
\hline BBAL & Black-browed albatross & Diomedea melanophrys & 15 \\
\hline GHAL & Grey-headed albatross & Diomedea chrysostoma & 15 \\
\hline LMSA & Light-mantled sooty albatross & Phoebetria palpebrata & 1255 \\
\hline NGPE & Northern giant petrel & Macronectes halli & 89 \\
\hline WHPE & White-headed petrel & Pterodroma lessonii & 49 \\
\hline MOPE & Mottled petrel & Pterodroma inexpectata & 55 \\
\hline KEPE & Kerguelen petrel & Pterodroma brevirostris & 198 \\
\hline BLPE & Blue petrel & Halobaena caerulea & 606 \\
\hline PRSP & Prion spp. & Pachyptila spp. & 3006 \\
\hline WCPE & White-chinned petrel & Procellaria aequinoctialis & 2330 \\
\hline DKSH & Dark shearwater & Puffinus tenuirostris \& P. griseus & 598 \\
\hline \multirow[t]{2}{*}{ BBSP } & Black-bellied storm petrel & Fregetta tropica & 12 \\
\hline & Total observations & & 31847 \\
\hline
\end{tabular}

guins, grey-headed albatrosses, and white-headed and Kerguelen petrels being the exceptions) at least $15 \%$ of observations were within Assemblage 2. Resident species were the most commonly sighted species; constancies of southern fulmars, Cape petrels, Antarctic and snow petrels, and Wilson's storm petrels each exceeded $55 \%$. There were 10 indicator species/taxa (6 breeding and 4 non-resident) identified. This assemblage was most frequently observed in midsummer (late November to early March, $90 \%$ of assemblage sightings), and contracted to a narrow spatial band lying at approximately 64 to $67^{\circ} \mathrm{S}$ during $2 \mathrm{mo}$, from the second half of January to mid-March (Fig. 4).

The third assemblage included observations of all 26 species but was dominated numerically by the non-breeding species/taxa that visit Prydz Bay each summer. A total of 10 indicator species/ taxa was identified, comprising 2 resident species (Cape petrel and Wilson's storm petrel) and 8 non-resident species of albatrosses, petrels, prion spp., and

Assemblage 1 comprised 24 species/taxa, and included 10 indicator species (comprising all 9 Prydz Bay resident breeding species [Woehler 1991], and Arctic terns, which are summer migrants to the area). Fidelities of emperor and Adélie penguins, snow petrels, south polar and sub-Antarctic skuas, and Arctic terns exceeded $60 \%$, while constancies for Adélie penguins, southern fulmars, and Antarctic and snow petrels exceeded $50 \%$. This assemblage was observed for all months in which data were collected (late September to early May). Although confounded by the sparsity of observations during the early and late summer season, the temporal and spatial pattern of observations is consistent with the influx, presence and departure of breeding individuals of the 9 resident species within the Prydz Bay area. The early season broad regional extent of this assemblage contracted to the extreme southeast of Prydz Bay (adjacent to the extensive breeding areas in the Vestfold Hills and on the Rauer Group in the southeast of Prydz Bay, Woehler \& Johnstone 1991) during mid summer (Fig. 4).

Assemblage 2 comprised all 26 species/taxa reported from Prydz Bay, and represented an overlap assemblage. For all but 4 of the 26 species (emperor pen- shearwaters. Fidelities of 6 species/taxa exceeded $70 \%$ and constancies of prion spp. and white-chinned petrels exceeded $74 \%$. This assemblage was observed from the second half of December to mid March each year (92\% of assemblage sightings), and was well offshore (north of $65^{\circ} \mathrm{S}$ ) (Fig. 4).

Two species were found to be indicator species in all 3 assemblages - Cape petrel and Wilson's storm petrel (Figs. 2 \& 3). These results reflect their breeding status within Prydz Bay (Woehler \& Johnstone 1991) and consequently within at-sea assemblages of breeding species, but their occurrence in association with non-

Table 2. Spearman correlations among environmental variables within Prydz Bay, East Antarctica 1980/81 to 2001/02 $\left({ }^{*} \mathrm{p}<0.01\right)$

\begin{tabular}{|lccr|}
\hline & Sea state & $\begin{array}{c}\text { Sea surface } \\
\text { temperature }\end{array}$ & Latitude \\
\hline Sea-ice concentration & $-0.44^{*}$ & $-0.59^{*}$ & $-0.10^{*}$ \\
Sea state & & $0.46^{*}$ & $0.21^{*}$ \\
Sea surface temperature & & $0.16^{*}$ \\
\hline
\end{tabular}



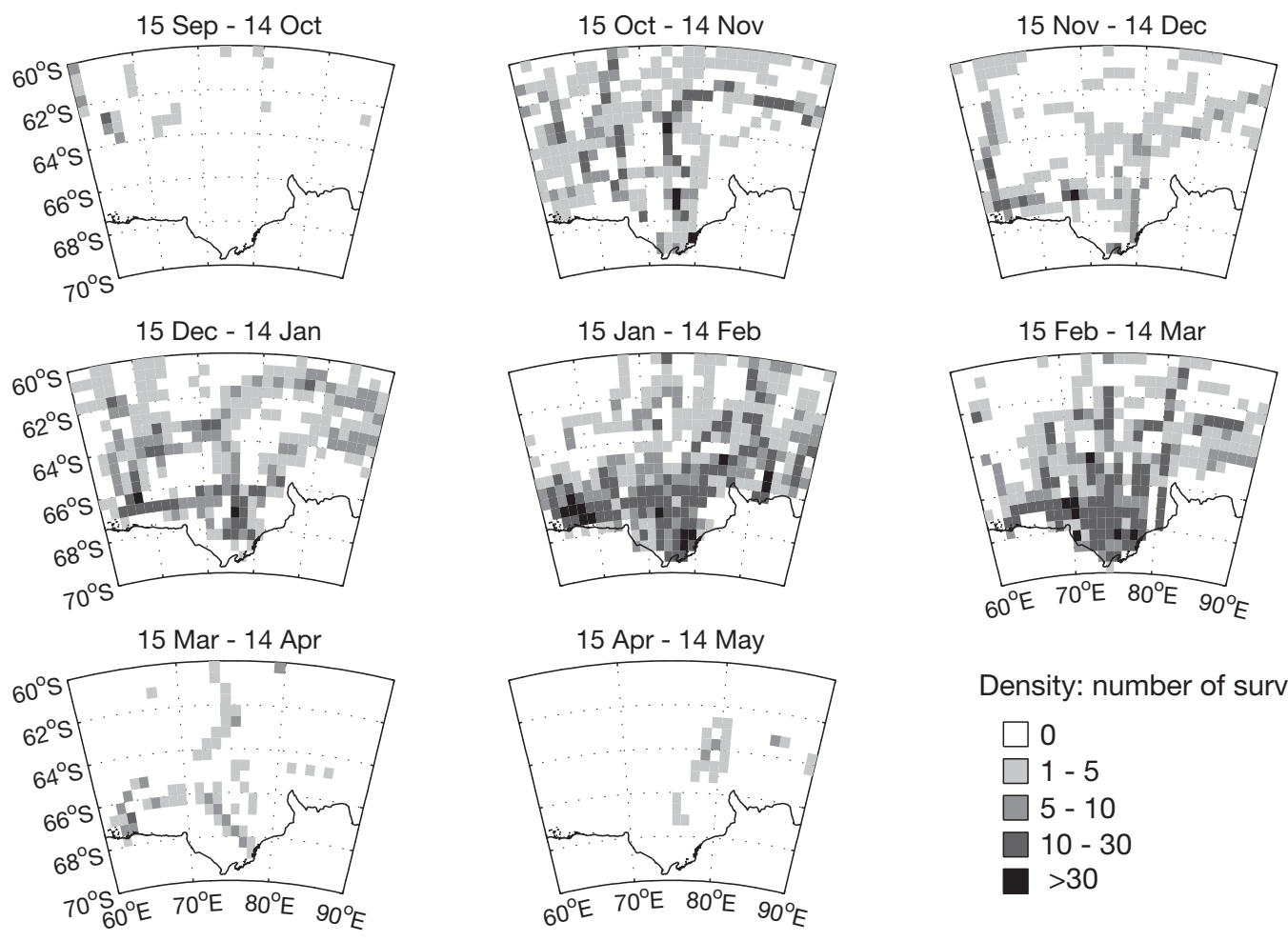

Density: number of surveys

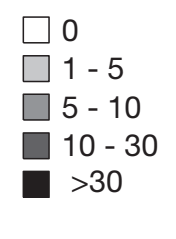

Fig. 1. Distribution maps of 10 min seabird at-sea surveys within Prydz Bay, 1980/81 to 2001/02

breeding species is likely to be a result of individuals of these species moving into Prydz Bay from more northerly subAntarctic breeding populations at localities such as Heard Island $\left(53^{\circ} \mathrm{S}, 73^{\circ} \mathrm{E}\right)$, approximately $1000 \mathrm{~km}$ to the northwest of Prydz Bay (Woehler 1991).

\section{Temporal patterns in seabird assemblages in Prydz Bay}

The Prydz Bay data were divided into 2 decadal and 4 semi-decadal periods and the assemblage analyses repeated. For the periods 1980/81-1990/91 and 1991/92-2001/02, the analyses again revealed the same 3 assemblages. The species composition (determined by fidelity and constancy) and spatiotemporal ranges of these assemblages were virtually identical to those obtained from analyses of the entire data set. The differences were mainly in the few infrequently-observed species that contributed minimally to the assemblages. For example, grey-headed albatrosses were entirely associated with Assem-
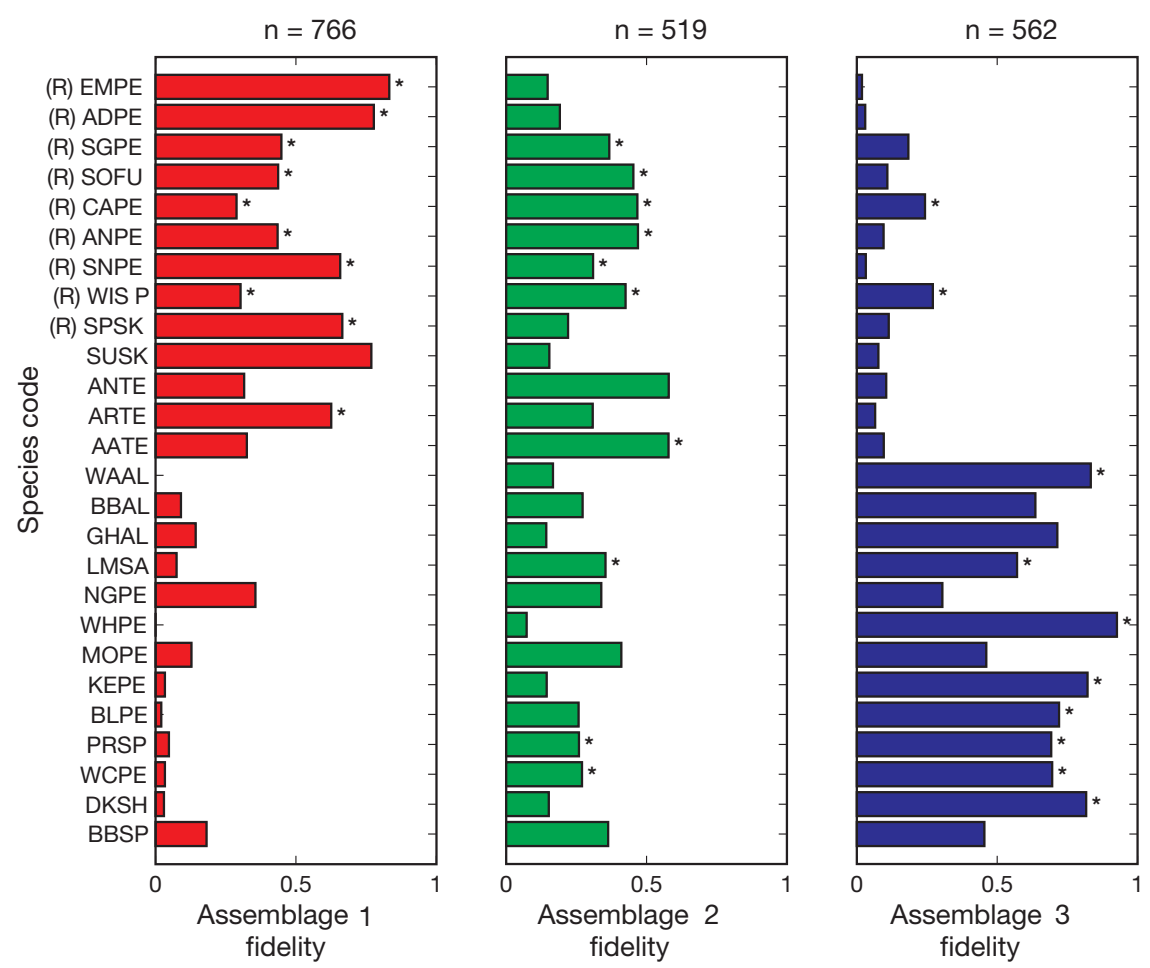

Fig. 2. Species composition and fidelities for the 3 seabird assemblages within Prydz Bay identified in this study. Species codes are given in Table 1 ; those species that breed within Prydz Bay are indicated by (R). Species/taxa with a fidelity-constancy product of 0.05 or greater are marked with an asterisk. The number of sites (see 'Materials and methods') is shown above each assemblage 


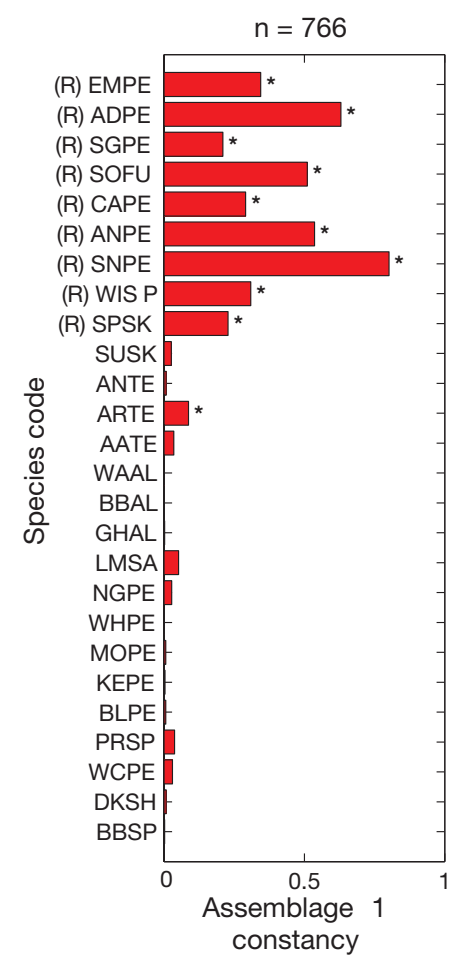

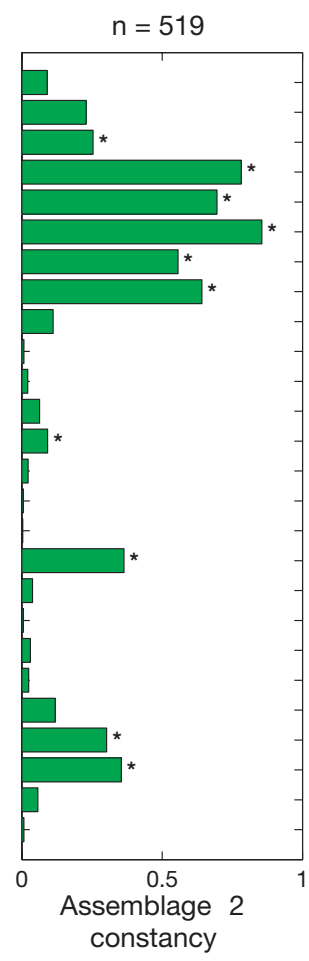

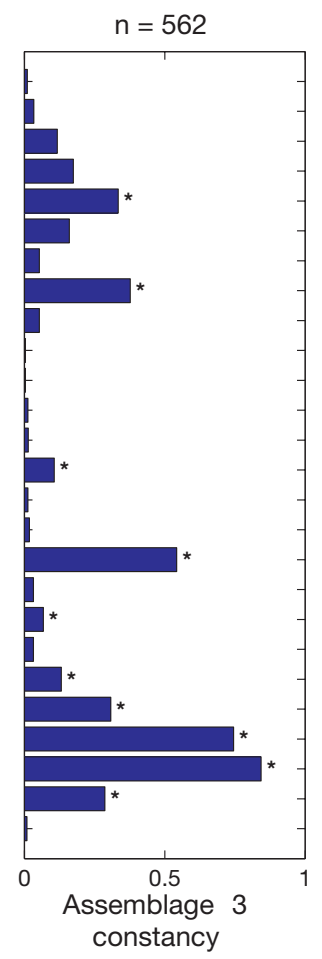

Fig. 3. Species composition and constancies for the 3 seabird assemblages within Prydz Bay identified in this study. Species codes are given in Table 1 ; those species that breed within Prydz Bay are indicated by (R). Species/taxa with a fidelity-constancy product of 0.05 or greater are marked with an asterisk. The number of sites (see 'Materials and methods') is shown above each assemblage

\section{Physical environmental characteristics associated with seabird assemblages}

The relationships between these seabird assemblages and characteristics of the physical environment were explored using a classification tree approach. The null misclassification rate (obtained by always predicting the assemblage to be the most common one, namely Assemblage 1) was $57.5 \%$. Trees built using all environmental variables as predictors (sea surface temperature, sea-ice, sea state, cloud cover, precipitation, wind force and air pressure) indicated that just 3 variables (sea surface temperature, sea state, and sea-ice) were of value in predicting assemblages. These 3 variables yielded a tree with 5 leaf nodes and a cross-validation (CV) error of $37.7 \%$. The misclassification matrix of this tree revealed that the assemblage-by-assemblage misclassification rate was $26.8 \%$ for Assemblage 1, $58.1 \%$ for Assemblage 2, and $33.5 \%$ for Assemblage 3, suggesting that Assemblage 2 in particular is poorly characterised by the physical environment alone.

Adding latitude to the above 3 predictors reduced the misclassification rate to $30.6 \%$ (8 leaf nodes on the tree, misclassification rate by assemblage: Assemblage 1: $25.0 \%$, Assemblage 2: $45.8 \%$, Assemblage 3: $18.2 \%$ ) This tree (pruned to 6 leaf nodes for clarity, pruned misclassification rate $32.1 \%$ ) is shown in Fig. 5. The structure of this tree reveals that sites with more than $9 \%$ sea-ice concentration are almost exclusively populated by Assemblage 1, as are sites south of $67^{\circ} \mathrm{S}$. Assemblage 2 was best characterised by latitude. This assemblage is found predominantly in sites with less than $9 \%$ sea-ice ( 239 of 351 sites, $68 \%$ ), and mostly between 67 and $65.6^{\circ} \mathrm{S}$, but also as far north as $63.5^{\circ} \mathrm{S}$ in sites with sea surface temperatures less than $0.4^{\circ} \mathrm{C}$. Assemblage 3 was found in warmer, open waters and more northerly latitudes (as is clearly evident in Fig. 4).

Sea-ice, sea surface temperature, sea state, and latitude covaried (Table 2). The primary split in both trees (with and without latitude) was on sea-ice coverage of $9 \%$. Examining the competing variables shows that sea surface temperature was equally as useful as sea-ice (an equal improvement in predictive accuracy was obtained with a split on sea surface temperature of less than $0^{\circ} \mathrm{C}$ ). Sea state less than $0.5 \mathrm{~m}$ was the next most powerful split, with an improvement of $18 \%$ less than the im- 
provements obtained when splitting on either sea-ice or sea surface temperature. Sea surface temperature could be used as a surrogate for sea-ice cover, with $84.9 \%$ agreement; while the agreement between sea-ice split and sea state split was $77.7 \%$. Temporal variables (year, month and day-of-year) did not add any extra predictive accuracy to the above tree. In the tree shown in Fig. 5, the second split is on latitude south of $65.6^{\circ} \mathrm{S}$. This lead to a much greater improvement in predictive accuracy than the next most powerful variable (sea surface temperature, improvement $65.1 \%$ ). Surrogates for latitude south of $65.6^{\circ} \mathrm{S}$ were sea surface temperature $<0.1^{\circ} \mathrm{C}(67.1 \%$ agreement), sea state less than $0.5 \mathrm{~m}$ (65.9\%) and sea-ice greater than $3 \%(61.3 \%)$.

\section{Seabird associations within Prydz Bay}

The similarities between the spatiotemporal ranges of the 26 species/taxa of seabirds observed within Prydz Bay over the 22 yr study period are described schematically by the cluster dendrogram in Fig. 6. This dendrogram is the result of a hierarchical cluster analysis, wherein joining species/taxa or species/taxa groups with similar spatiotemporal ranges at each step formed associations of seabirds. Truncating the dendrogram at a dissimilarity level of 8 yields 2 broad associations, identified in Fig. 6 as (a) and (b).

Association (a) includes 14 species/taxa, and is broadly similar to Assemblage 1 (Figs. 2 \& 3). Ten of these 14 species (the 9 resident species that breed within Prydz Bay and 1 migratory species, the Arctic tern), account for more than $98 \%$ of observations of this association. The remaining 4 members of this association are migratory and non-resident (to Prydz Bay) species (northern giant petrel, Antarctic/Arctic terns, Antarctic terns and subAntarctic skuas). Association (a) can be subdivided into 2 sub-associations, one of 6 species (Association (a1), comprising emperor and Adélie penguins, southern fulmar, Antarctic and snow petrels and south polar skuas), all of which are restricted to Antarctic breeding localities, and a second sub-association (a2) of 4 species, comprising Wilson's storm petrel, Cape petrel, southern giant petrel and Arctic terns. The 3 petrels in this second sub-association breed around Prydz Bay, but also breed farther north on sub-Antarctic islands, and this subassociation may reflect an association of southward movement of birds from more northerly breeding local-
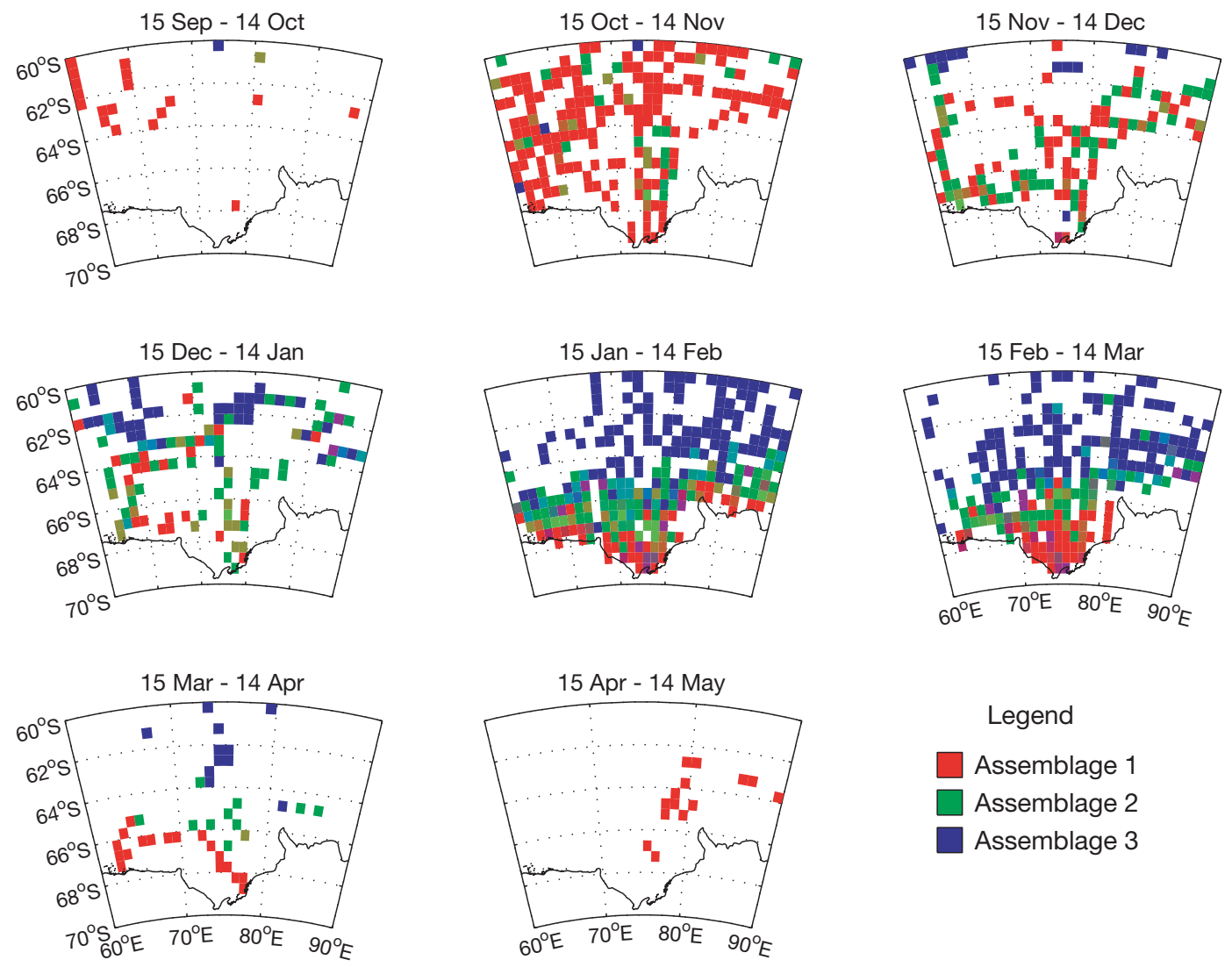

Legend

Assemblage 1

Assemblage 2

Assemblage 3

Fig. 4. The distributions of the 3 seabird assemblages within Prydz Bay by month, partitioned into bins of $0.5^{\circ}$ latitude by $1^{\circ}$ longitude; the red, green, and blue colour component of each bin has been determined by the fraction of sites within the bin belonging to Assemblages 1, 2 and 3. Data from all years are shown; areas with no data are white 


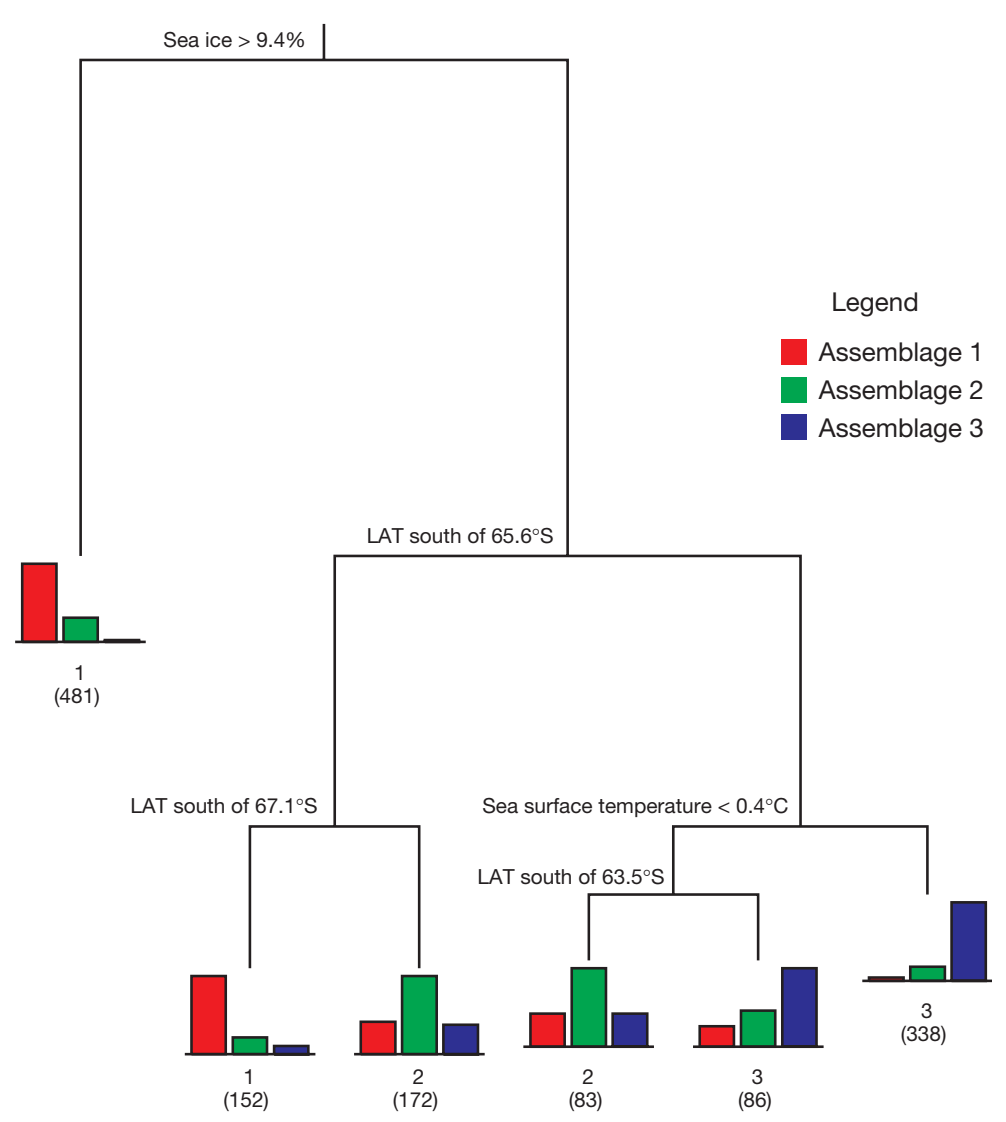

Fig. 5. Classification tree of assemblages by environment and latitude (LAT). The depth of the tree below each split is proportional to the improvement in prediction error obtained by the split. The histogram at each leaf node shows the relative distribution of assemblage types of the sites within the node. The number beneath each leaf node indicates the dominant assemblage of the node, and the number in brackets indicates the number of sites within the node

ities. This result supports our previous suggestion that Cape petrels and Wilson's storm petrel, present in all 3 assemblages, form an identifiable association based on the combination of their Antarctic and sub-Antarctic breeding localities and their at-sea behaviour within Prydz Bay. The second species association, marked as (b) on Fig. 6, comprises 12 species/taxa, of which 5 (blue petrel, light-mantled sooty albatross, prion spp., whitechinned petrel and dark shearwater) account for almost $95 \%$ of observations of this association. This association is very similar to the non-resident species composition of Assemblage 3 (Figs. 2 \& 3 ).

\section{DISCUSSION}

\section{Limitations to the study}

Several potential sources of error or bias are present within this study. The first is that numerous observers collected the data used in this study. It is impossible to correct for inter-observer biases (Ryan \& Cooper 1989), and particularly so in multi-decadal studies where there are numerous observers. To some extent this bias is mitigated by a majority of the seabird observations being collected by observers who were present on multiple voyages.

The second potential source of error is the presence of the vessel influencing the behaviour at sea of the seabirds observed (Ryan \& Cooper 1989). Some species are known to be attracted to vessels (e.g. albatrosses, skuas and fulmarine petrels, Ryan \& Cooper 1989, Woehler 1997). However, we do not know if other species ignore or deliberately avoid vessels. The potential for a vessel to attract a bird from within a radius of approximately $30 \mathrm{~km}$ (a proposed horizon for a foraging bird) will not influence the results reported here as the spatial scale of the seabird groupings is much larger than this distance. Additionally, the analyses are based on presence and absence information only, and so any potential over-estimation of numbers of individuals due to an attraction to the ship is not applicable.

Ship-following behaviour is also a potential source of error within this study. Six species had more than $10 \%$ of observations with the behaviour code 'following wake': whitechinned petrels $(39.5 \%$ of observations), Cape petrels $(21.1 \%)$, light-mantled sooty albatrosses (17.2\%), black-browed and greyheaded albatrosses (13.3\% each), and wandering albatrosses (10.8\%). It seems unlikely, however, that short-term ship following behaviour (extending for between several hours and 1 to 2 d) would significantly alter the patterns reported here. The spatiotemporal distribution of sightings of Cape petrels, when separated into wake-following and nonwake-following groups, showed no visually apparent difference. This was also the case with sightings of light-mantled sooty and wandering albatrosses. The distribution of white-chinned petrels did show a difference when examined in this manner: $90 \%$ of whitechinned petrel sightings during the period from late December to early January, and south of $64^{\circ} \mathrm{S}$, were recorded as wake following, suggesting that whitechinned petrels might not normally venture into this region at this time of year. However, white-chinned petrel sightings in this spatial and temporal range account for only a small fraction $(2.1 \%)$ of total whitechinned petrel sightings. There were no other visually apparent differences between the distributions of wake- 
following and non-wake-following sightings of whitechinned petrels. We note that white-chinned petrel records reported as 'wake following' between mid December and mid January south of $64^{\circ} \mathrm{S}$ extended approximately $1.5^{\circ}$ farther south than non-wake following records for the same time period. This may be interpreted as an index to the extent of the influence of ship attraction for this species. Grey-headed and black-browed albatross sightings were each less than 20 in number and so it is difficult to infer much from these few records for these species.

\section{Effect of spatial and temporal scales}

For our analyses, we pooled consecutive observations on a single voyage within maxima of $12 \mathrm{~h}$ and $50 \mathrm{~km}$ into composite records, or sites (see 'Materials and methods'). This reduced the number of data by a factor of 5 (important for extended-dissimilarity calculations where the computational demands scale approximately with the square of the number of data points). The pooling of records also served to reduce the sparsity of the observations, thus making the results of clustering easier to interpret. The scale of this data pooling is much less than the scale of the patterns observed, and thus we do not believe the methodologies used in this study will have generated spurious results.

\section{Seabird assemblages within Prydz Bay, and compari- son with other Southern Ocean seabird assemblages}

Almost all of the seabird at-sea research in the Southern Ocean has been conducted in the South Atlantic sector of the Southern Ocean, with some work conducted in the Ross Sea; very little has been conducted around the remaining $75 \%$ of the Antarctic coastline. Eakin et al. (1986) identified 3 seabird assemblages during a late autumn (May to June) voyage to the South Atlantic Ocean. They identified an Antarctic assemblage of Antarctic and snow petrels, and 3 species of penguin (chinstrap, gentoo and macaroni). A second assemblage identified by them was a 'wide-ranging' assemblage of numerous species of petrels, albatrosses, storm petrels and shearwaters. The third assemblage was that of 'temperate' species, comprising petrels, shearwaters and penguins. All 3 assemblages were characterised by sea surface temperatures. Fraser \& Ainley (1986) described 2 assemblages, one associated with the pack-ice (emperor \&

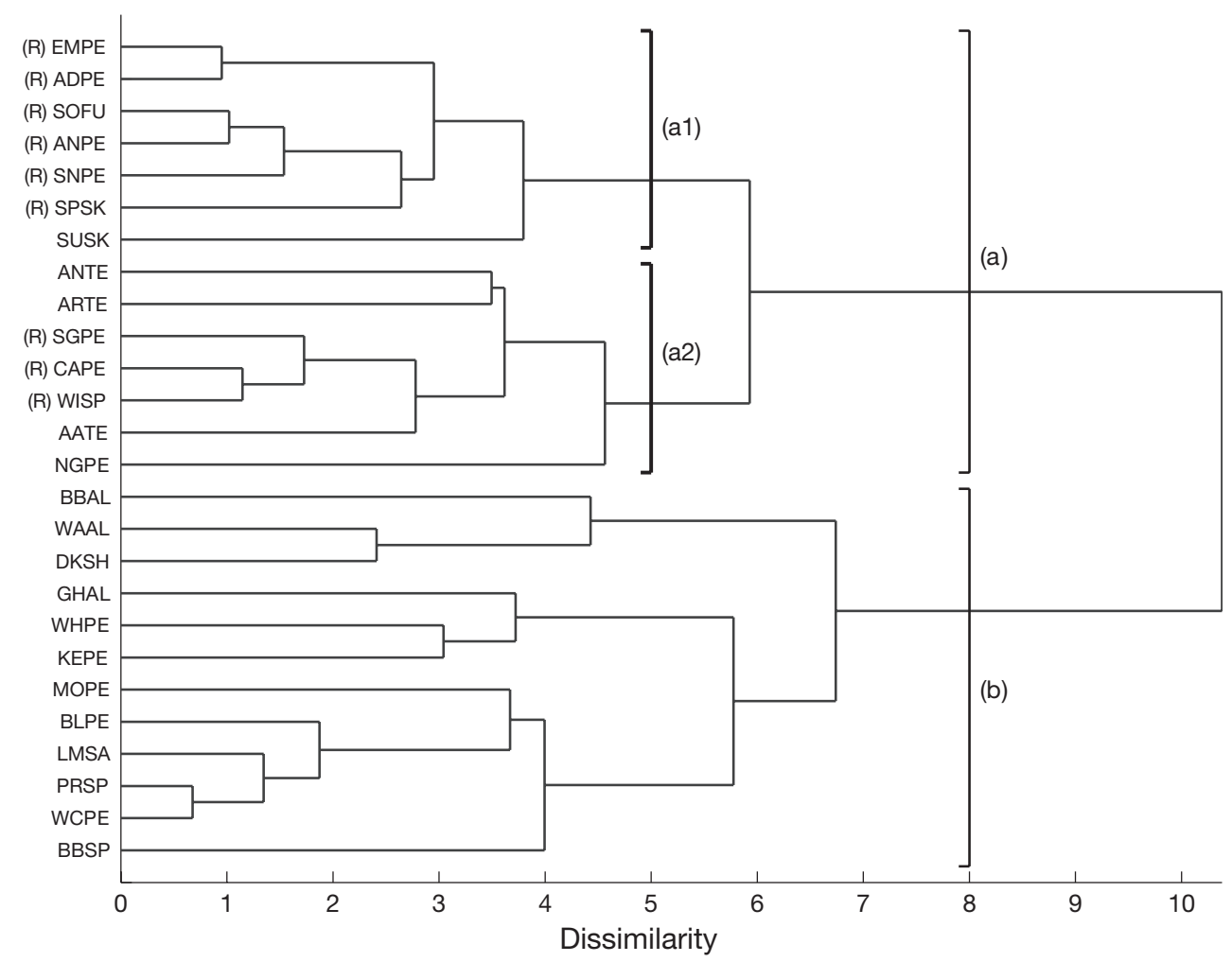

Fig. 6. Dendrogram of spatiotemporal at-sea ranges of seabirds within Prydz Bay, 1980/81 to 2001/02. Species codes are given in Table 1 ; those species that breed within Prydz Bay are indicated by $(\mathrm{R})$ 
Adélie penguins, Antarctic and snow petrels) and the other associated with open water (southern fulmar, Cape petrel, Wilson's storm petrel and mottled petrel). The species' strong fidelities to their respective habitats were proposed as indicative of the important role that pack-ice played in structuring Antarctic seabird communities.

Hunt et al. (1990) described 5 seabird assemblages in the southern Drake Passage and Bransfield Strait, based on observations of only 10 species/taxa. Nine of the 10 species/taxa observed in southern Drake Passage and Bransfield Strait were also observed in Prydz Bay (the remaining species, chinstrap penguin, does not breed in East Antarctica: Woehler \& Johnstone 1991). The 5 seabird assemblages described by Hunt et al. (1990) were associated with surface water properties and water mass characteristics, and they inferred a role of prey distributions related to water properties in influencing the seabird community compositions observed. Ainley et al. $(1992,1993)$ identified 2 major assemblages in the seabirds observed in the South Atlantic sector of the Southern Ocean. The pack-ice assemblage comprised Antarctic and snow petrels, Adélie and emperor penguins and southern fulmar. The open-water assemblage comprised king and chinstrap penguins, Kerguelen petrels, blue and cape petrels, Antarctic prion and southern giant petrel.

Woehler $(1995,1997)$ described the seabird community within Prydz Bay for the period 1980/81 to 1992/93 as comprised 9 breeding species and 15 non-resident species/taxa that were present during the summer months. The results of this study confirms this presence of these 2 assemblages (Assemblages 1 and 3), and in addition, clearly shows that their at-sea distributions overlap in both time and space, resulting in the formation of Assemblage 2.

\section{Stability of seabird assemblages}

The species compositions and spatiotemporal distributions of the 3 assemblages were found to be consistent across different time periods. With shorter temporal scales the variances increased, but the results obtained from the 20 yr analyses were replicated with only minor differences at decadal and semi-decadal scales. There was a change in indicator status of wandering albatrosses and prion spp. from the 1980/81$1990 / 91$ period to the 1991/92-2001/02 period. The result for wandering albatrosses can be attributed to a significant decrease in their presence within Prydz Bay (Woehler 1996, Woehler \& Watts 2000). However, we are unable to suggest a reason for the change in indicator status for prion spp.
The remaining species were found in the same assemblages and were distributed in time and space in Prydz Bay similarly at semi-decadal, decadal, and $20 \mathrm{yr}$ scales. We conclude that the seabird assemblages reported here for Prydz Bay in the 1980/81 to 2001/02 period are identifiable at finer temporal scales, at least to 5 yr periods.

Ribic \& Ainley (1988/89) and Ainley et al. (1993) suggested that the species composition of the seabird assemblages associated with Antarctic pack-ice might be some of the least variable of all seabird assemblages. The species composition of the open-water assemblage was more variable as it also included seasonal migrants. The species composition of the pack-ice assemblage identified by Ribic \& Ainley (1988/89) and Ainley et al. (1993) is a subset of Assemblage 1 identified in this study, with the differences in species composition reflecting local breeding distributions. Thus our results support the proposal (Ribic \& Ainley 1988/89, Ainley et al. 1993) that the pack-ice assemblage is consistent around the Antarctic. To some extent, this consistency may be an artefact of the relatively low species diversity of high-latitude breeding seabirds present in the Antarctic ( 9 breeding species: Watson 1975).

\section{Unexpected outcomes}

An unexpected outcome of the current study was the detection of errors in species identification. In the results reported here, Antarctic terns, Arctic terns and Antarctic/Arctic terns have been treated as discrete taxa, but the cluster analyses showed broadly similar distributions, suggesting that, for the Prydz Bay area at least, some misidentification of individual terns occurred, since there are no breeding populations of Antarctic terns in Prydz Bay, and the nearest breeding populations are well to the north on sub-Antarctic islands, from which the terns migrate even farther north. Thus the sightings of Antarctic terns in Prydz Bay (as defined for this study) are almost certainly misidentification of migratory Arctic terns rather than identification of resident Antarctic terns.

\section{Into the future}

This is the first study to examine and quantify seabird at-sea community composition in the Southern Ocean at decadal scales. This study complements previous studies conducted elsewhere around the Antarctic, and is in agreement with their findings, suggesting that the observed assemblages have circum-antarctic distributions, differing only in species composition due 
to species' breeding distributions at regional scales. This study provides the foundation for further investigations, for example predicting seabird distributions from physical environmental parameters at localities elsewhere in the Southern Ocean adjacent to East Antarctica. Successful predictions would lend further support to proposals for ecosystem-scale seabird assemblages and associations identified here for Prydz Bay and previously for the Ross Sea and Antarctic Peninsula regions, in addition to the role of physical environmental parameters in influencing seabird associations and assemblages.

The potential effect(s) of long-term (20 yr) decreases in 4 species of seabirds within Prydz Bay on seabird community composition (Woehler 1996, Woehler \& Watts 2000, E. J. Woehler unpubl. data) has been masked in this study by the use of presence-absence data for analyses. Future analyses will incorporate numerical abundances, permitting an assessment of the species composition of the seabird community over a range of temporal scales, the extent of inter-annual variability, and quantification of the finer-scale (intrato inter-annual) role of the physical environment in influencing the species composition of the seabird community within Prydz Bay. These studies are also expected to provide greater understanding of the role of physical environmental parameters on the species composition of seabird communities in the Southern Ocean adjacent to the Antarctic.

Acknowledgements. We thank L. Belbin and M. Riddle for their ongoing encouragement and support. G. Cruickshank, C. Hodges, B. Priest and F. Spruzen entered much of the data in preparation for analyses. We thank all observers who have recorded seabird at-sea observations over the past $22 \mathrm{yr}$. G. De'ath (Australian Institute of Marine Science) provided valuable statistical advice.

Appendix 1. Species/taxa $(\mathrm{n}=14)$ recorded on fewer than 10 occasions (no. shown) within Prydz Bay 1980/81 to 2001/02

\begin{tabular}{|lll|}
\hline Kelp gull & Larus dominicanus & 1 \\
Common diving petrel & Pelecanoides urinatrix & 1 \\
White-bellied storm petrel & Fregetta grallaria & 3 \\
Grey petrel & $\begin{array}{l}\text { Procellaria cinerea } \\
\text { White-headed/ }\end{array}$ & 1 \\
sterodroma lessonii/ & 2 \\
Soft-plumaged petrel & P. mollis & \\
Great-winged petrel & Pterodroma mollis & 9 \\
Sooty albatross & Pterodroma macroptera & 8 \\
Sooty/light- & $\begin{array}{c}\text { Phoebetria fusca } \\
\text { mantled sooty albatross }\end{array}$ & 3 \\
Yellow-nosed albatross & Phalpebrata & 4 \\
& Chlororarche & \\
Buller's albatross & Thalassarche bulleri & 2 \\
Black-browed albatross & Thalassarche melanophrys & 3 \\
Chinstrap penguin & Pygoscelis antarctica & 2 \\
King penguin & Aptenodytes patagonicus & 2 \\
\hline
\end{tabular}

\section{LITERATURE CITED}

Abrams RW (1985) Environmental determinants of pelagic seabird distribution in the African sector of the Southern Ocean. J Biogeogr 12:473-492

Ainley DG, Jacobs SS (1981) Sea-bird affinities for ocean and ice boundaries in the Antarctic. Deep-Sea Res 28A: $1173-1185$

Ainley DG, O'Connor EF, Boekelheide RJ (1984) The marine ecology of birds in the Ross Sea, Antarctica. Ornithol Monogr 32

Ainley DG, Fraser WR, Sullivan CW, Torres JJ, Hopkins TL, Smith WO (1986) Antarctic mesopelagic micronekton: evidence from seabirds that pack ice affects community structure. Science 232:847-849

Ainley DG, Ribic CA, Fraser WR (1992) Does prey preference affect habitat choice in Antarctic seabirds? Mar Ecol Prog Ser 90:207-221

Ainley DG, Ribic CA, Spear LB (1993) Species-habitat relationships amongst Antarctic seabirds: a function of physical or biological factors? Condor 95:806-816

Ainley DG, Ribic CA, Fraser WR (1994) Ecological structure among migrant and resident seabirds of the ScotiaWeddell Confluence region. J Anim Ecol 63:347-364

Austin MP, Belbin L (1982) A new approach to the species classification problem in floristic analysis. Aust J Ecol 7:75-89

Brieman L, Friedman JH, Olshen RA, Stone CG (1984) Classification and regression trees. Wadsworth International Group, Belmont

Cooper J, Woehler EJ (1994) Consumption of Antarctic krill (Euphausia superba) by seabirds during summer in the Prydz Bay region, Antarctica. In: El-Sayed SZ (ed) Southern Ocean ecology: the BIOMASS perspective. Cambridge University Press, Cambridge, p 247-260

De'ath G (1999) Extended dissimilarity: a method of robust estimation of ecological distances from high beta-diversity data. Plant Ecol 144:191-199

Dufrêne M, Legendre P (1997) Species assemblages and indicator species: the need for a flexible asymmetrical approach. Ecol Monogr 67:345-366

Eakin RR, Dearborn JH, Townsend WC (1986) Observations of marine birds in the South Atlantic Ocean in the late austral autumn. In: Kornicker LS (ed) Biology of the Antarctic Seas XVII. Antarctic Research Series 44. American Geophysical Union, Washington, DC, p 69-86

Fraser WR, Ainley DG (1986) Ice edges and seabird occurrence in Antarctica. BioScience 36:258-263

Griffiths AM (1983) Factors affecting the distribution of the snow petrel (Pagodroma nivea) and the Antarctic petrel (Thalassoica antarctica). Ardea 71:145-150

Griffiths AM, Siegfried WR, Abrams RW (1982) Ecological structure of a pelagic seabird community in the Southern Ocean. Polar Biol 1:39-46

Hunt GL, Heinemann D, Veit RR, Heywood RB, Everson I (1990) The distribution, abundance and community structure of marine birds in southern Drake Passage and Bransfield Strait, Antarctica. Cont Shelf Res 10:243-257

Nicol S, Pauly T, Bindoff NL, Wright S, Thiele D, Hosie GW, Strutton PG, Woehler E (2000) Sea ice, circulation and the East Antarctic ecosystem. Nature 406:504-507

Ribic CA, Ainley DG (1988/89) Constancy of seabird species assemblages: an exploratory look. Biol Oceanogr 6:175-202

Ryan PG, Cooper J (1989) Observer precision and bird conspicuousness during counts of birds at sea. S Afr J Mar Sci 8:271-276

Watson GE (1975) Birds of the Antarctic and Subantarctic. American Geophysical Union, Washington, DC 
Woehler EJ (1990) The distribution of seabird biomass in the Australian Antarctic Territory: implications for conservation. Environ Conserv 17:256-261

Woehler EJ (1991) Status and conservation of the seabirds of Heard Island and the McDonald Islands. In: Croxall JP (ed) Seabird status and conservation: a supplement. International Council for Bird Preservation, Cambridge, p 263-277

Woehler EJ (1995) Variability in foraging ecology and food consumption by seabirds at high latitudes. PhD thesis, University of California, Irvine, CA

Woehler EJ (1996) Concurrent decreases in 5 species of Southern Ocean seabirds in Prydz Bay. Polar Biol 16: 379-382

Woehler EJ (1997) Seabird abundance, biomass and prey

Editorial responsibility: Otto Kinne (Editor),

Oldendorf/Luhe, Germany consumption within Prydz Bay, Antarctica, 1980/81 to 1992/93. Polar Biol 17:371-383

Woehler EJ, Johnstone GW (1991) Status and conservation of the seabirds of the Australian Antarctic Territory. In: Croxall JP (ed) Seabird status and conservation: a supplement. International Council for Bird Preservation, Cambridge, p 279-308

Woehler EJ, Watts DJ (2000) Long term decreases in albatrosses and petrels in Prydz Bay, East Antarctica. Mar Ornithol 28:152

Woehler EJ, Cooper J, Croxall JP, Fraser WR and 9 others (2001) A statistical assessment of the status and trends of Antarctic and Subantarctic seabirds. SCAR/CCAMLR/ NSF, USA, SCAR, Cambridge

Submitted: August 6, 2002; Accepted: January 15, 2003

Proofs received from author(s): March 21, 2003 